\title{
Neo-Industrial Base for Sustainable Development of Raw-Materials Cluster
}

\author{
Sergey Zhironkin ${ }^{1, *}$, Svetlana Demchenko ${ }^{2}$, Gennady Kayachev ${ }^{2}$, Marina Ryzhkova $^{3}$, and \\ Olga Zhironkina ${ }^{4}$ \\ ${ }^{1}$ T.F. Gorbachev Kuzbass State Technical University, 650000 Kemerovo, 28 Vesennya st., \\ Kemerovo, Russia \\ ${ }^{2}$ Siberian Federal University, 660075 Lida Prushinskaya St. 2, Krasnoyarsk, Russia \\ ${ }^{3}$ National Research Tomsk State University, 63405036 Lenin ave., Tomsk, Russia \\ ${ }^{4}$ Plekhanov Russian University of Economics, Kemerovo branch, 650992, pr. Kuznetskiy, 39, \\ Kemerovo, Russia
}

\begin{abstract}
Today the issues of overcoming the environmental consequences of the negative structural shift of the Russian economy, accelerating the rate of economic growth, reducing the technological and social-and-economic separation from developed countries are becoming strategically in demand for extractive clusters. The need for methodological and theoretical support of the neo-industrialization of the Russian economy raises the urgency of analyzing ways to solve environmental problems, relying on reducing the share of raw materials production in the gross regional product. The emergence of an innovative paradigm raises environmental requirements for industry, raises the priority of interaction institutions between the state, science and business in the process of reducing environmental damage. The leading role is played by the analysis of innovative nature protection activities in extractive clusters and structuring the competitive advantages of the economy, not related to the export of raw materials.
\end{abstract}

\section{Introduction}

The current structure of the Russian economy, developed within the framework of the rawmaterials model, is not able to solve the problems of environment pollution along with the growth in the volume of mining. In the high entropy condition for energy prices, it became obvious that without neo-industrial changes, the recovery of the manufacturing industry on a new convergence and technological basis, the enhancement of the knowledge-intensive industries, the instability of the macroeconomic system and environmental risks increase, sustainable development will lose its basis.

\section{Materials and Methods}

\footnotetext{
* Corresponding author: zhironkin@inbox.ru
} 
Today, Russia produces more coal than it can consume. According to different information, more than 10 million tons are in warehouses and they are already full. The increase in production is mainly due to Kuzbass - about 360 million tons of coal are produced every year, about half are exported. $70 \%$ of the fuel is produced by the open method because it is cheaper. The environmental consequences of such production are not taken into account. The Russian government intends to increase domestic consumption, as well as exports, reducing the share of gas and, correspondingly, increasing the share of coal. According to the state program for the development of the coal industry, by 2030 the share of coal in energy consumption should increase by one and a half times. A number of power plants with a total capacity of more than 10 giga-watts will be put into operation between 2020 and 2022 years [1-3].

It is planned to export 50 billion kilowatt-hours to China, to increase the percentage of supplies to the Asian market from 5\% to $16 \%$. However, it is not clear as far as the government's plans coincide with the opportunities, since not only Europe refuses coal, but China also reduces its consumption. In 2014, coal mining companies had suffered losses for the first time there. In 2016 there was a drop in demand. In general, the coal industry is in deep crisis. Up to half of the coal enterprises in the world are operating at a loss. In part, this is the result of steadily low prices for coal [4-6].

Kuzbass is the largest coal basin Russia. It produces almost $60 \%$ of all Russian coal; there are 120 coal-mining enterprises (66 mines and 54 openings) and 52 concentrating plants and machines. In Kuzbass opencast mining is increasing due to its profitability. But coal cuts cause terrible damage to the environment and human health. Intensive open pit mining causes landslides and even earthquakes [7-8].

Unfortunately, nowadays the technogenic impact on the nature of any coal enterprise remains unregulated, because the legislative base is not ready to assess the environmental damage caused to nature by man's heavy activity, despite the fact that it is a large-scale impact on the ecosystem. The consequences of such an impact are different. First, this is a geomechanical effect, the consequence of which is the displacement of the surface, the change in the structure of the relief, which leads to a disruption of the geodynamic situation as a whole. That is why most of the settlements in Kuzbass so sharply reacted to the last year Altaic earthquake: as is known, seismic waves are transmitted through zones of tectonic faults that characterize the relief of the Kuznetsk Basin. Moreover, under many mining cities there are so-called hydraulic cushions which violated the stability of the soil. A similar effect on the stability of the geodynamic equilibrium of the territory is exerted by mass explosions in mines and pits. Kuzbass is a unique region in terms of the scale of man-made impact on nature: the area of the coal basin is not too large, but the density of coal, chemical and metallurgical enterprises does not have world analogues. The cities of the region are traditionally leading in the rating of the most ecologically unfavorable settlements of the country.

\section{Results and Discussion}

The problem of atmospheric air pollution is the most acute of the environmental problems of the Kemerovo region. In 2004 the total mass of pollutant emissions from stationary and mobile sources was almost 1.4 million tons. The structure of emissions of pollutants is dominated by hydrocarbons and carbon monoxide. Intensive open pit mining causes landslides and even earthquakes. The largest share in emissions of stationary sources is made by enterprises of the fuel industry, metallurgy, energy and housing and utilities infrastructure.

Another very dangerous consequence of human intervention in environment selfregulation, according to scientists, is the water crisis that threatens the Kuzbass. All natural water inflows are violated, including mines and pits being closed. Often, coal open pits are 
developed to a depth of 350 meters, that exhausts groundwater reservoirs which are at a level of 200 meters.. Kuzbass will soon stay without drinking water.

Most of the industrial potential and population of the region are concentrated in the Tom river basin, which is the main source of water supply and the main wastewater receiver. The volume of fresh water used in the Kemerovo region in the whole is estimated at about 2 billion cubic meters per year. The most water-intensive industries of the national economy in the region are energy, housing and utilities infrastructure, ferrous and non-ferrous metallurgy. In the structure of pollutants, nitrates, ammonium nitrate, general phosphorus, fluorine are predominant.

High contamination of surface and groundwater in the region creates a tense situation in providing the population with drinking water of high standard quality. The protection of groundwater from depletion and pollution at existing water intakes is in most cases unsatisfactory. Potential sources of groundwater pollution are numerous non-working and non-liquidated wells. The most intensive underground waters are polluted in the zones of influence of numerous storage tanks of industrial and agricultural drains.

Effective management of environmental activities in the region is possible only with the consolidation of the executive power and the specially authorized federal body in the field of environmental protection. To this end, the United Main Department of Natural Resources and Environmental Protection of the Ministry of Natural Resources of Russia for the Kemerovo Region was established in the region. A targeted environmental program until 2010 was established in the region, according to which mining enterprises will have to deal thoroughly with the environment: to restore 70,000 hectares of previously disturbed lands, to put hundreds of rivers and reservoirs in order in the region. The geological service of the region is charged to develop measures that will increase the amount of appropriations for geological exploration, including through investments of subsoil users. The environmental protection organizations are engaged in improving the regulatory and legal framework in the field of waste management, protection of atmospheric air and charging for pollution of the environment, including chemical and metallurgical enterprises. Now, industrial companies will have to pay for each hectare of land, for each spring, and to accept the terms of local authorities concerning environmental protection and social policy. For an objective assessment of the environmental situation in the region, it is planned to revive the system of environmental monitoring and re-create a network of environmental monitoring laboratories.

The obsolete structures that predominate in Kuzbass economy and corresponding to the end of the 19th and the beginning of the 20th century give rise to a number of social-andeconomic problems, such as the predominance of low-skilled labor, the unequal interregional exchange in terms of value added, low labor productivity in value terms, the presence of mono-towns - industrial enterprises - with a difficult social situation, etc.

In Kuzbass the development of production of modern 5th and the newest 6th layers is inevitably associated with the intensification of R \& D. But in this the area falls behind other regions of Western Siberia. So, the peak of innovation activity was in 2006, when according to the data of the Department of Education and Science of the Kemerovo Region Administration, 275 applications for inventions (4th place) were submitted in the region, passing the Novosibirsk region (625), the Krasnoyarsk region (424) ) and the Tomsk Region (406 applications). And the diversification directions of the regional economy laid down in the Investment Passport of the Kemerovo Region are, somehow, connected with the raw materials industries and do not provide a technological upgrade beyond the 4th layer (development of energy complexes on the basis of coal enterprises, underground gasification of coal, methane extraction from coal seams, and technological support of the mining industry and specialized machine building, new compact production of special grades of steels, as well as technological complexes of metal processing). As the main investors within these directions are, again, the largest commodity groups - the main owners in Kuzbass. 
Consequently, within the existing sectoral, institutional and technological structure of the region's economy, it is impossible to switch to new technological structures, with a departure from mono-sectoral commodity policies, from the monopoly dominance of large holdings, from the use of obsolete and physically worn out equipment. It is important to note that the structural problems of Kuzbass economy have significantly worsened in the current crisis. In the end of 2008 - the beginning of 2009 the situation in Kuzbass economy threatened to grow from a crisis to a catastrophic one. Thus, out of 30 million tons of coal unrealized by the beginning of 2009, only 12 million tons were sold. On the verge of bankruptcy were 12 coalmining and 3 metallurgical enterprises (producing $11 \%$ and $33 \%$ of coal and metal in the region, respectively). By mid-2009, 58\% of industrial and $39 \%$ of civil capital construction were frozen; the number of unemployed increased by $4 \%$. As a result, the production and investment "imbalance" of the region's economy towards raw materials industries in 20082009 intensified even more: in 2008-2009 investments in coal processing amounted to only $18 \%$ of the coal industry in the region, in engineering $-11 \%$ of the investment in the regional metallurgical complex. In regional exports, the share of processing coal and coal chemistry is $6 \%$ of the export of "raw" coal, and the volume of export of engineering products is in 9 times less than the product of metallurgy exported outside the region. As a result, in 20082012 the processing enterprises received only $17.5 \%$ of total investments in the regional industry, while the level of depreciation of their fixed capital exceeded $55 \%$.

We clarified the definition of neo-industrialization of the economy - not only as significant changes in its technological and industrial structure (the development of new hightech industries, the integration of science and production), but primarily as a systemic state policy of regulation of the entire reproduction mechanism, with forming it economic relations in the sphere of investment, the accumulation of investment resources, the accumulation of capital, production and distribution of the finished product. Such neo-industrial structural transformations must affect the social basis of reproduction, the spatial distribution of productive forces, and the technological base of the economy.

However, the existing structure of the Russian economy, which is formed in the conditions of technological degradation of industry, monopolization and tycoonization of the economic system, significantly reduces the prospects for neo-industrialization and causes the macroeconomic inconsistency of the implementation of the innovative scenario. Therefore today, more than ever, theoretical understanding of purposeful structural transformations of the economy is required, which will allow Russia to enter the neo-industrial way of development.

The neo-industrialization of the region's economy means overcoming the de-industrial problems of its structure in the process of innovative development of the coal, metallurgical and chemical industries, the formation of new forms of investment relations, and the changing role of the state.

Technological basis of neo-industrially-oriented structural transformations of the economy of the Kemerovo region is a convergence of innovations in the basic branches of the economy of the region. This means the formation of new branches of deep processing of raw materials extracted in Kuzbass - bio-coal fuel, composite polymers and semiconductors, ultra-light alloys, restoration of coal engineering and automation, development of recuperation thermal power.

The neo-industrial role of the state in the economy of the Kemerovo region is to institutionalize its structural transformations; to form new subjects of the economy investment, innovative banks; to increase the investment attractiveness of technological development, technology transfer and lobbying.

The investment component of the neo-industrialization of the region's economy includes the development of public-private investment partnerships in the innovation sphere, guaranteeing investments in the deep processing of raw materials on the basis of convergent 
technologies, issuing subordinated loans to create regional guarantee and insurance funds for investing in industrial innovations.

The neo-industrial conditions for the growth of social well-being in the economy of the Kemerovo region are the increase of added value in the production chain, the primary and deep processing of raw materials, the creation of intellectual rent and its distribution among the subjects of innovation activity in the industry of the region.

The concept of structural reforms in the economy of the Kemerovo region must meet the following requirements: the determinism of market reforms by Russian problems and the specific structure of the region's economy; adequacy of deep regional economic structure problems; accounting for actual factors of change in meso-economic proportions; addressing the future developers of legislative frameworks and programs for transforming the economic structure of the Kuzbass.

\section{Conclusion}

Ecological literacy of production managers requires not only specific professional knowledge, but also a high level of general ecological culture. Solving the problems of environmental safety is associated with heavy activities both at the level of serious scientific research and at the educational level. Environmental education of the new generation is an urgent task. Science says that it is impossible to influence the nature with impunity, since the consequences of such an impact are unpredictable and can be catastrophic.

\section{References}

1. M. Tyulenev, Y. Lesin, E. Tyuleneva, E. Murko, E3S Web of Conferences, 15, 02003 (2017)

2. J. Janočko, M. Cehlár, Z. Šimková, Economics and Innovation Management, 3, 32-45 (2017) DOI: 10.26730/2587-5574-2017-3-32-45

3. N.N. Golofastova, V.G. Mikhailov, I.V., Seredyuk I.V. Economics and Innovation Management, 1, 66-75 (2017) DOI: 10.26730/2587-5574-2017-1-66-75

4. M. Cehlár, J. Janočko, Z. Šimková, T. Pavlik, E3S Web of Conferences, 15, 01019 (2017)

5. M., Prokudina, O. Zhironkina, O. Kalinina, M. Gasanov, F. Agafonov, E3S Web of Conferences, 21, 04003 (2017)

6. Z. Šimková, M. Cehlár, H. Pavolová, Acta Montanistica Slovaca, 21:3, 208-216 (2016)

7. M. Cehlár, P. Varga, Z. Jurkasová, M. Pašková, Geotherm and geothermal power plant decisions and conditions, Acta Montanistica Slovaca, 15 (SPEC.ISSUE 2), 132-138 (2011)

8. M. Cehlár, L. Mihok, Theoretical and Empirical Researches in Urban Management, 8:4, 60-72 (2013) 